\title{
Electrochemical oxidation of anesthetic tetracaine in aqueous medium. Influence of the anode and matrix composition
}

\author{
Carlota Ridruejo $^{\mathrm{a}}$, Claudio Salazar ${ }^{\mathrm{b}}$, Pere L. Cabot ${ }^{\mathrm{a}}$, Francesc Centellas ${ }^{\mathrm{a}}$, Enric Brillas ${ }^{\mathrm{a}, *}$, Ignasi Sirés ${ }^{\mathrm{a}, *}$ \\ a Laboratori d'Electroquímica dels Materials i del Medi Ambient, Departament de Química Física, Facultat de Química, Universitat de Barcelona, Martí i Franquès 1-11, 08028 \\ Barcelona, Spain \\ ${ }^{\mathrm{b}}$ Facultad de Ciencias Químicas, Laboratorio de Trazas Elementales y Especiación (LabTres), Universidad de Concepción, 4070371, Edmundo Larenas 129, Concepción, Chile
}

\section{A R T I C L E IN F O}

Article history:

Received 27 March 2017

Received in revised form 28 April 2017

Accepted 29 April 2017

Available online xxx

Keywords:

Active chlorine

BDD

Electrochemical oxidation

Hydroxyl radical

Tetracaine

Wastewater treatment

\begin{abstract}
A B S T R A C T
The degradation of $150 \mathrm{~mL}$ of $0.561 \mathrm{mM}$ tetracaine hydrochloride at $\mathrm{pH} 3.0$ by electrochemical oxidation with electrogenerated $\mathrm{H}_{2} \mathrm{O}_{2}\left(\mathrm{EO}-\mathrm{H}_{2} \mathrm{O}_{2}\right)$ has been studied at a low current density of $33.3 \mathrm{~mA} \mathrm{~cm}$ in three different matrices: $0.050 \mathrm{M} \mathrm{Na}_{2} \mathrm{SO}_{4}$, real urban wastewater and a simulated matrix mimicking its electrolyte composition. Comparative trials were performed in an undivided cell with a $3 \mathrm{~cm}^{2}$ boron-doped diamond (BDD), $\mathrm{Pt}, \mathrm{IrO}_{2}$-based or $\mathrm{RuO}_{2}$-based anode and a $3 \mathrm{~cm}^{2}$ air-diffusion cathode that allowed continuous $\mathrm{H}_{2} \mathrm{O}_{2}$ electrogeneration. In $0.050 \mathrm{M} \mathrm{Na}_{2} \mathrm{SO}_{4}$, much faster and overall removal of tetracaine occurred using BDD because of the large oxidation ability of $\operatorname{BDD}(\mathrm{OH})$ formed from anodic water oxidation. In either simulated matrix or real wastewater, the $\mathrm{RuO}_{2}$-based anode yielded the quickest tetracaine decay due to a large production of active chlorine from anodic oxidation of $\mathrm{Cl}^{-}$. For the mineralization of the organic matter content, the BDD/air-diffusion cell was the best choice in all aqueous matrices, always reaching more than $50 \%$ of total organic carbon abatement after $360 \mathrm{~min}$ of electrolysis, as expected if BDD $(\mathrm{OH})$ mineralizes more easily the chloroderivatives formed from tetracaine oxidation in the presence of active chlorine. The initial $\mathrm{N}$ of tetracaine was partly transformed into $\mathrm{NO}_{3}{ }^{-}$, although the total nitrogen of all solutions always decayed by the release of volatile by-products. In the $\mathrm{Cl}^{-}$-containing matrices, significant amounts of $\mathrm{ClO}_{3}{ }^{-}$and $\mathrm{ClO}_{4}{ }^{-}$ were obtained using BDD, whereas active chlorine was much largely produced using the $\mathrm{RuO}_{2}$-based anode. Five aromatic by-products, one of them being chlorinated, along with low concentrations of oxalic acid were identified. The change in toxicity during EO- $\mathrm{H}_{2} \mathrm{O}_{2}$ with BDD in the sulfate and simulated matrices was also assessed.
\end{abstract}

\section{Introduction}

Thousands of tons of a large number of pharmaceuticals are consumed worldwide by humans and animals. Since they are not completely metabolized, they are continuously discharged into the environment via urine and feces. This mainly affects water bodies and, eventually, the quality of drinking water supplies. Despite their low contents at $\mu \mathrm{g} \mathrm{L}^{-1}$ level, the potential impact of pharmaceuticals on ecosystems and their long-term effects on the health of living beings have caused global alarm [1-4]. The occurrence of pharmaceuticals in water is explained by their incomplete removal by conventional physicochemical and biological treatments in wastewater treatment plants (WWTPs), thereby becoming persistent contaminants [3,4]. Tetracaine (2-dimethylaminoethyl-4-butylaminobenzoate, $\mathrm{C}_{15} \mathrm{H}_{24} \mathrm{~N}_{2} \mathrm{O}_{2}, \quad M=264.3 \mathrm{~g} \mathrm{~mol}^{-1}$ ), commercially available as hydrochloride salt, is a potent local anesthetic belonging to the family of amino esters. It is used for topical anaesthesia in ophthalmology, spinal anaesthesia and nerve block and can be formulated as solu-

\footnotetext{
* Corresponding authors.

Email addresses: brillas@ub.edu (E. Brillas); i.sires@ub.edu (I. Sirés)
}

tions, creams, gels and as the base of ointments [5,6]. Its critical toxicity has been determined [7], and it has been detected in hospital wastewater with an average concentration of $0.48 \mu \mathrm{g} \mathrm{L}^{-1}$ [8]. No previous work has reported the decontamination of water containing tetracaine. Research efforts are then necessary to show if this pharmaceutical can be destroyed in aqueous medium in order to prevent its toxic effects on living beings.

Advanced oxidation processes (AOPs) are powerful oxidation methods characterized by the continuous generation of reactive oxygen species (ROS) like hydroxyl radical $(\mathrm{OH})$. Since these species are formed in situ without addition of noxious chemicals, they are considered as eco-friendly technologies [9]. The very short lifetime of $\circ \mathrm{OH}\left(\sim 10^{-9} \mathrm{~s}\right)$ and its very high standard reduction potential $\left(E^{\circ}=2.8\right.$ $\mathrm{V} / \mathrm{SHE}$ ) allow its fast, non-selective reaction with most organics, showing a second-order rate constant $\left(k_{2}\right)$ of $10^{7}-10^{10} \mathrm{M} \mathrm{s}^{-1}$, up to total mineralization in many cases $[10,11]$. For this reason, AOPs have got great interest for water remediation. Among these methods, electrochemical oxidation (EO) has been widely utilized as an electrochemical AOP (EAOP) that combines a large oxidation power with simplicity of use [11-13]. EO involves the destruction of organic pollutants in a free-chlorine aqueous medium through physisorbed hydroxyl radicals $(\mathrm{M}(\mathrm{OH}))$ originated at the surface of an 
anode $\mathrm{M}$ from water oxidation [13-15]:

The nature of the anode has major influence on the oxidation ability of EO. Materials such as Pt and dimensionally stable anodes (DSA ${ }^{\circledR}$ ) based on $\mathrm{IrO}_{2}$ and $\mathrm{RuO}_{2}$ behave as active anodes with low production of physisorbed $\mathrm{M}(\mathrm{OH})$ since it is transformed into an less powerful superoxide (MY) species [13,16-20]. In contrast, large amounts of physisorbed $\mathrm{M}\left({ }^{\circ} \mathrm{OH}\right)$ are formed at non-active anodes with large $\mathrm{O}_{2}$-overvoltage. It has been found that boron-doped diamond (BDD) thin-film electrodes are the most powerful among the latter ones, having high corrosion stability in harsh media and hampering a strong adsorption of ${ }^{\circ} \mathrm{OH}$ on their surface. BDD allows a large degree of mineralization of aromatics including pharmaceuticals [14,15,19-31], with much quicker removal compared to that obtained using traditional anodes such as $\mathrm{Pt}[32,33]$ and $\mathrm{PbO}_{2}$ [34].

The situation is very different if $\mathrm{EO}$ is performed in a chlorinated medium, since active chlorine species $\left(\mathrm{Cl}_{2}, \mathrm{HClO}\right.$ and/or $\left.\mathrm{ClO}^{-}\right)$are produced from $\mathrm{Cl}^{-}$oxidation at the anode $[9,11-13]$ :

$$
2 \mathrm{Cl}^{-} \rightarrow \mathrm{Cl}_{2}(\mathrm{aq})+2 \mathrm{e}^{-}
$$

$$
\mathrm{Cl}_{2}(\mathrm{aq})+\mathrm{H}_{2} \mathrm{O} \rightarrow \mathrm{HClO}+\mathrm{Cl}^{-}+\mathrm{H}^{+}
$$

$$
\mathrm{HClO} \leftrightarrows \mathrm{ClO}^{-}+\mathrm{H}^{+} \quad \mathrm{p} K_{\mathrm{a}}=7.56
$$

Under these conditions, physisorbed $\mathrm{M}\left({ }^{\circ} \mathrm{OH}\right)$ and active chlorine species compete to oxidize the organic matter. It has been found that active DSA ${ }^{\circledR}$ anodes, pre-eminently $\mathrm{RuO}_{2}$-based ones, yield larger quantity of active chlorine that can attack rapidly the aromatic structures, even more quickly than $\operatorname{BDD}\left({ }^{\circ} \mathrm{OH}\right)[20,36]$. However, highly persistent chloroderivatives are usually accumulated, giving rise to partial mineralization of solutions.

The EO process can be alternatively applied using continuous generation of $\mathrm{H}_{2} \mathrm{O}_{2}$ from the two-electron cathodic reduction of injected $\mathrm{O}_{2}$ or air via reaction (5) [12,35-37], giving rise to the so-called EO with electrogenerated $\mathrm{H}_{2} \mathrm{O}_{2}\left(\mathrm{EO}-\mathrm{H}_{2} \mathrm{O}_{2}\right)$ process:

$$
\mathrm{O}_{2}+2 \mathrm{H}^{+}+2 \mathrm{e}^{-} \rightarrow \mathrm{H}_{2} \mathrm{O}_{2}
$$

Several carbonaceous cathodes such as activated carbon fiber [38], carbon nanotubes [39], carbon felt [40,41] and carbon-polytetrafluoroethylene (PTFE) gas-diffusion composites $[20,42,43]$ have shown good performance for $\mathrm{H}_{2} \mathrm{O}_{2}$ generation from reaction (5).

In EO- $\mathrm{H}_{2} \mathrm{O}_{2}$, the electrogenerated $\mathrm{H}_{2} \mathrm{O}_{2}$ is partly destroyed to $\mathrm{O}_{2}$ at the anode $\mathrm{M}$ yielding the hydroperoxyl radical $\mathrm{M}\left(\mathrm{HO}_{2}{ }^{\circ}\right)$ from reaction (6) $[11]$ :

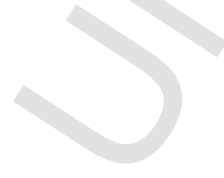

and hence, organics can be removed by different ROS, being M( $\left.{ }^{\circ} \mathrm{OH}\right)$ much more powerful than $\mathrm{H}_{2} \mathrm{O}_{2}$ and $\mathrm{M}\left(\mathrm{HO}_{2}{ }^{\circ}\right)$. In our laboratory, we have shown the potential applicability of EO- $\mathrm{H}_{2} \mathrm{O}_{2}$ to degrade some pharmaceuticals with a carbon-PTFE air-diffusion cathode
$[20,33,43]$. This cathode has been chosen since it is the most effective for $\mathrm{O}_{2}$ reduction from reaction (5), avoiding the possible cathodic reduction of organics.

This work aims to assess the oxidation ability of EO- $\mathrm{H}_{2} \mathrm{O}_{2}$ to destroy tetracaine using an undivided cell with an air-diffusion cathode. The degradation was comparatively performed in pure sulfate medium, as well as in a simulated matrix with chloride + sulfate ions as model electrolytes to better understand its further destruction in a real wastewater matrix that contained large amounts of both ions along with natural organic matter (NOM, which mainly includes humic, fulvic and tannic acids). $\mathrm{A} \mathrm{pH}$ of 3.0 was chosen to compare the present results with those obtained under similar conditions using Fenton-based EAOPs in future work. Four anodes including BDD, $\mathrm{Pt}, \mathrm{IrO}_{2}$-based and $\mathrm{RuO}_{2}$-based were tested to establish the best electrolytic system. The pharmaceutical decay and mineralization rate were studied for each system and matrix. Primary by-products were identified by gas chromatography-mass spectrometry (GC-MS). Final carboxylic acids were detected by ion-exclusion high-performance liquid chromatography (HPLC) and the change in toxicity was determined from the standard method based on the change in bioluminescence of Vibrio fischeri bacteria.

\section{Materials and methods}

\subsection{Reagents}

Tetracaine hydrochloride ( $>99 \%$ purity), oxalic acid dihydrate (99\% purity) and fumaric acid (99\% purity) were supplied by Sigma-Aldrich. $\mathrm{Na}_{2} \mathrm{SO}_{4}, \mathrm{NaCl}, \mathrm{NH}_{4} \mathrm{Cl}, \mathrm{K}_{2} \mathrm{SO}_{4}$ and $\mathrm{NaNO}_{3}$, used as background electrolytes, were of analytical grade from Panreac, Probus and Prolabo. Synthetic and analytical solutions were prepared with ultrapure water obtained from a Millipore Milli-Q system with resistivity $>18 \mathrm{M} \Omega \mathrm{cm}$ at $25^{\circ} \mathrm{C}$. The initial $\mathrm{pH}$ was adjusted to 3.0 with analytical grade $\mathrm{H}_{2} \mathrm{SO}_{4}$ for sulfate solutions and analytical grade $\mathrm{HClO}_{4}$ for the other water matrices, both of them supplied by Merck. All the other reagents and solvents needed for analysis were of analytical or HPLC grade purchased from Panreac and Merck.

\subsection{Aqueous matrices}

The electrolytic experiments were performed with three different aqueous matrices:

(i) A real wastewater was obtained from the secondary effluent of a WWTP located in Gavà-Viladecans (Barcelona, Spain) that treats ca. $50,000 \mathrm{~m}^{3} \mathrm{~d}^{-1}$ of urban and selected industrial wastewater. The samples were preserved in a refrigerator at $4{ }^{\circ} \mathrm{C}$ before use. Its main characteristics were: $\mathrm{pH} 8.1$, specific conductivity of $1.73 \mathrm{mS} \mathrm{cm}^{-1}, 12.2 \mathrm{mg} \mathrm{L}^{-1}$ of total organic carbon (TOC); cations concentration: $212 \mathrm{mg} \mathrm{L}^{-1} \mathrm{Na}^{+}, 34 \mathrm{mg} \mathrm{L}^{-1} \mathrm{~K}^{+}$, $86 \mathrm{mg} \mathrm{L}^{-1} \mathrm{Ca}^{2+}, \quad 24 \mathrm{mg} \mathrm{L}^{-1} \mathrm{Mg}^{2+}, \quad 0.19 \mathrm{mg} \mathrm{L}^{-1} \mathrm{Fe}^{2+}$ and $36.9 \mathrm{mg} \mathrm{L}^{-1} \mathrm{NH}_{4}^{+}$; anions content: $141.3 \mathrm{mg} \mathrm{L}^{-1} \mathrm{SO}_{4}{ }^{2-}, 318 \mathrm{mg}$ $\mathrm{L}^{-1} \mathrm{Cl}^{-}, 0.85 \mathrm{mg} \mathrm{L}^{-1} \mathrm{NO}_{3}^{-}$and $0.79 \mathrm{mg} \mathrm{L}^{-1} \mathrm{NO}_{2}^{-}$.

(ii) A simulated matrix mimicking the above ionic content, but without organic load, was prepared in ultrapure water. It was composed of $0.80 \mathrm{mM} \mathrm{Na}_{2} \mathrm{SO}_{4}, \quad 10 \mathrm{mM} \mathrm{NaCl}, \quad 1.5 \mathrm{mM} \mathrm{NH}_{4} \mathrm{Cl}$, $0.5 \mathrm{mM} \mathrm{K}_{2} \mathrm{SO}_{4}$ and $0.02 \mathrm{mM} \mathrm{NaNO}_{3}$, yielding $\mathrm{pH} 5.1$ and conductivity of $1.79 \mathrm{mS} \mathrm{cm}^{-1}$.

(iii) A synthetic solution with $0.050 \mathrm{M}$ of a typical non-chlorinated electrolyte such as $\mathrm{Na}_{2} \mathrm{SO}_{4}$, yielding $\mathrm{pH} 7.0$ and conductivity of $6.89 \mathrm{mS} \mathrm{cm}^{-1}$, was used for comparison.

Once the solution $\mathrm{pH}$ was adjusted to 3.0 in all cases, the conductivity rose up to $2.22,2.01$ and $7.53 \mathrm{mS} \mathrm{cm}^{-1}$ for the real wastewater, 
simulated matrix and sulfate solution, respectively. These values only varied slightly during all the $\mathrm{EO}-\mathrm{H}_{2} \mathrm{O}_{2}$ processes tested.

\subsection{Electrochemical system}

The EO- $\mathrm{H}_{2} \mathrm{O}_{2}$ treatment of all tetracaine hydrochloride solutions was conducted with a conventional two-electrode, one-compartment glass tank reactor containing $150 \mathrm{~mL}$ of solution, which was vigorously stirred with a magnetic bar at $800 \mathrm{rpm}$. The cell was surrounded with a jacket for water recirculation through a thermostat to regulate the solution temperature to $35^{\circ} \mathrm{C}$. Four anodes of $3 \mathrm{~cm}^{2}$ area were alternately tested: (i) a boron-doped diamond (BDD) thin film over Si substrate supplied by NeoCoat (Le-Chaux-de-Fonds, Switzerland), (ii) a Pt sheet of $99.99 \%$ purity supplied by SEMPSA (Barcelona, Spain), (iii) an $\mathrm{IrO}_{2}$-based plate and (iv) a $\mathrm{RuO}_{2}$-based plate, the two latter being supplied by NMT Electrodes (Pinetown, South Africa). The cathode was always a $3 \mathrm{~cm}^{2}$ carbon-PTFE air-diffusion electrode purchased from Sainergy Fuel Cell (Chennai, India). It was mounted as described elsewhere [22] and continuously produced $\mathrm{H}_{2} \mathrm{O}_{2}$ upon air feeding at flow rate of $1 \mathrm{~L} \mathrm{~min}^{-1}$. The distance between the anode and cathode was kept to about $1 \mathrm{~cm}$. Trials were performed under galvanostatic conditions by using a constant current density $(j)$ provided by an Amel 2049 potentiostat-galvanostat. The cell voltage was measured with a Demestres 601BR digital multimeter. Before the electrolytic treatment of the pharmaceutical solutions, the surface of all electrodes was electrochemically cleaned/activated by polarization in $0.050 \mathrm{M} \mathrm{Na}_{2} \mathrm{SO}_{4}$ at $j=100 \mathrm{~mA} \mathrm{~cm}{ }^{-2}$ for $180 \mathrm{~min}$.

\subsection{Analytical procedures}

The electrical conductance and $\mathrm{pH}$ of solutions were measured on a Metrohm 644 conductometer and a Crison GLP 22 pH-meter, respectively. Prior to analysis, the samples were filtered with $0.45 \mu \mathrm{m}$ PTFE membrane filters supplied by Whatman. $\mathrm{H}_{2} \mathrm{O}_{2}$ content in electrolyzed synthetic solutions was obtained from the light absorption of its Ti(IV) complex at $\lambda=408 \mathrm{~nm}$, measured on an Unicam UV/ Vis spectrophotometer at $25^{\circ} \mathrm{C}$ [44]. Active chlorine concentration was determined by the $N, N$-diethyl-p-phenylenediamine colorimetric method at $\lambda=515 \mathrm{~nm}$ using a Shimadzu $1800 \mathrm{UV} / \mathrm{Vis}$ spectrophotometer [45].

The TOC content of the pharmaceutical solutions with $\pm 1 \%$ accuracy was measured by injecting $50 \mu \mathrm{L}$ aliquots into a Shimadzu VCSN TOC analyzer. Total nitrogen (TN) was obtained with a Shimadzu TNM-1 unit coupled to the above analyzer.

The tetracaine abatement and the evolution of generated carboxylic acids were followed by reversed-phase and ion-exclusion HPLC, respectively. These analyses were made upon injection of $10 \mu \mathrm{L}$ aliquots into a Waters 600 LC coupled with a Waters 996 photodiode array detector. For reversed-phase HPLC, the LC was fitted with a BDS Hypersil C18 $(250 \mathrm{~mm} \times 4.6 \mathrm{~mm})$ column at room temperature. A 50:50 (v/v) acetonitrile:water $\left(\mathrm{KH}_{2} \mathrm{PO}_{4} 10 \mathrm{mM}, \mathrm{pH} 3\right)$ at $1.0 \mathrm{~mL} \mathrm{~min}^{-1}$ was used as mobile phase, detecting the peak of tetracaine $(\lambda=311 \mathrm{~nm})$ at retention time $\left(t_{\mathrm{r}}\right)$ of $8.9 \mathrm{~min}$. For ion-exclusion HPLC, a Bio-Rad Aminex HPX 87H (300 mm $\times 7.8 \mathrm{~mm})$ column at $35^{\circ} \mathrm{C}$ was employed, whereas the mobile phase was $4 \mathrm{mM} \mathrm{H}_{2} \mathrm{SO}_{4}$ eluted at $0.6 \mathrm{~mL} \mathrm{~min}^{-1}$. The recorded chromatograms displayed peaks related to oxalic $\left(t_{\mathrm{r}}=6.8 \mathrm{~min}\right)$ and fumaric $\left(t_{\mathrm{r}}=14.7 \mathrm{~min}\right)$ acids at $\lambda=210 \mathrm{~nm}$.

The concentration of metal cations in the real wastewater was obtained by inductively coupled plasma-optical emission spectroscopy (IPC-OES), whereas the $\mathrm{NH}_{4}^{+}$concentration was obtained through the standard indophenol blue method using an Alpkem Flow Solution
IV flow injection system. The $\mathrm{Cl}^{-}, \mathrm{ClO}_{3}{ }^{-}, \mathrm{ClO}_{4}{ }^{-}, \mathrm{NO}_{3}{ }^{-}$and $\mathrm{SO}_{4}{ }^{2-}$ contents in initial and treated synthetic solutions were determined by ion chromatography upon injection of $20 \mu \mathrm{L}$ aliquots into a Kontron 465 LC fitted with a Waters IC-pack $(150 \mathrm{~mm} \times 4.6 \mathrm{~mm})$ anion column at $35{ }^{\circ} \mathrm{C}$, coupled with a Waters 432 conductivity detector. The mobile phase for this analysis was a solution of boric acid, sodium gluconate, sodium tetraborate, acetonitrile, butanol and glycerine eluted at $2 \mathrm{~mL} \mathrm{~min}^{-1}$ (EPA 9056).

Stable aromatic by-products originated at 30 and $120 \mathrm{~min}$ of EO- $\mathrm{H}_{2} \mathrm{O}_{2}$ treatment of $0.561 \mathrm{mM}$ of tetracaine hydrochloride in $0.050 \mathrm{M} \mathrm{Na}_{2} \mathrm{SO}_{4}$ and simulated matrix with a BDD/air-diffusion cell at $j=33.3 \mathrm{~mA} \mathrm{~cm}^{-2}$ were identified by means of GC-MS using a NIST05 data library. The organics accumulated in electrolyzed samples were concentrated by solid-phase extraction through repeated uptake using Agilent Bond Elute OMIX SPE pipette tips, followed by extraction with $2 \mathrm{~mL}$ of methanol as eluent. The GC-MS analysis was made with an Agilent Technologies 6890 N GC fitted with a non-polar Teknokroma Sapiens-X5 ms $(0.25 \mu \mathrm{m}, 30 \mathrm{~m} \times 0.25 \mathrm{~mm})$ column and coupled with an Agilent Technologies 5975C MS, which operated in electron impact mode at $70 \mathrm{eV}$. A temperature ramp of $36^{\circ} \mathrm{C}$ for $1 \mathrm{~min}, 5^{\circ} \mathrm{C} \mathrm{min}{ }^{-1}$ up to $325^{\circ} \mathrm{C}$ and hold time 10 min was applied, setting temperatures of 250,230 and $300{ }^{\circ} \mathrm{C}$ for the inlet, source and transfer line, respectively.

The toxicity of untreated and treated tetracaine hydrochloride solutions was determined as the effective concentration that reduces $50 \%$ of the bioluminescence intensity of Vibrio fischeri marine bacteria after $15 \mathrm{~min}$ of exposure at $25^{\circ} \mathrm{C}\left(\mathrm{EC}_{50}\right.$, in $\left.\mathrm{mg} \mathrm{L}^{-1}\right)$ using an AFNOR T90-301 Microtox ${ }^{\circledR}$ system. The bioluminescent bacteria and other reagents were provided by Modern Water (New Castle, USA) and the analysis was conducted following the standard Microtox ${ }^{\circledR}$ test recommended by the manufacturer. Each sample was adjusted to $\mathrm{pH} 7.0$ prior to measurement.

\section{Results and discussion}

\subsection{Tetracaine decay with different anodes and aqueous matrices}

Considering the very low conductivity of the simulated matrix and real wastewater, preliminary tests were made to ascertain the maximum $j$ value that could be employed for comparison between the different electrolytic systems in EO- $\mathrm{H}_{2} \mathrm{O}_{2}$ under the present experimental conditions. The trials were performed once the $\mathrm{pH}$ of both wastewater samples was adjusted to 3.0 with $\mathrm{HClO}_{4}$, which was employed as inert electrolyte to prevent interference with their sulfate + chloride content, which determines the oxidation ability of this EAOP $[9,11]$. The maximum $j$ was established as $33.3 \mathrm{~mA} \mathrm{~cm}^{-2}$, corresponding to a current of $100 \mathrm{~mA}$, since it gave rise to a cell voltage ca. $25 \mathrm{~V}$ for the simulated matrix in the BDD/air-diffusion cell. A higher voltage would be detrimental for the stability of the carbonaceous cathode and thus, this $j$ value was utilized in all subsequent assays.

Firstly, the ability for $\mathrm{H}_{2} \mathrm{O}_{2}$ electrogeneration in the different matrices at $\mathrm{pH} 3.0$ in the absence of pharmaceutical was examined using the BDD/air-diffusion cell at $33.3 \mathrm{~mA} \mathrm{~cm}^{-2}$ for $360 \mathrm{~min}$. No significant change in solution $\mathrm{pH}$ was observed during these runs. At the end of the electrolysis, $\mathrm{H}_{2} \mathrm{O}_{2}$ was accumulated up to $34.0 \mathrm{mM}$ in the $0.050 \mathrm{M} \mathrm{Na}_{2} \mathrm{SO}_{4}$ solution, $31.2 \mathrm{mM}$ in the simulated matrix and $25.1 \mathrm{mM}$ in the real wastewater. Taking into account that the Faraday's law predicts a maximum accumulation of $74.6 \mathrm{mM} \mathrm{H}_{2} \mathrm{O}_{2}$ under such conditions, the $46 \%$ of current efficiency found to produce this species in the $0.050 \mathrm{M} \mathrm{Na}_{2} \mathrm{SO}_{4}$ solution is indicative of its significant disappearance from reaction (6) originating the wreak radical $\operatorname{BDD}\left(\mathrm{HO}_{2}{ }^{*}\right)$ that is formed in concomitance with $\operatorname{BDD}(\mathrm{OH})$ gener- 
ated from reaction (1) $[9,20]$. The lower accumulation of $\mathrm{H}_{2} \mathrm{O}_{2}$ in the simulated matrix can be ascribed to its partial destruction through an additional waste reaction with $\mathrm{HClO}$, the pre-eminent active chlorine species formed at $\mathrm{pH} 3.0$ [11-13], as follows:

$$
\mathrm{HClO}+\mathrm{H}_{2} \mathrm{O}_{2} \rightarrow \mathrm{Cl}^{-}+\mathrm{O}_{2(g)}+\mathrm{H}_{2} \mathrm{O}+\mathrm{H}^{+}
$$

The larger $\mathrm{H}_{2} \mathrm{O}_{2}$ decay in the real wastewater compared to the other two matrices suggests the additional attack of this species on the NOM contained in it. One can thus infer that $\mathrm{H}_{2} \mathrm{O}_{2}$ will be also able to remove some organic load during the $\mathrm{EO}-\mathrm{H}_{2} \mathrm{O}_{2}$ treatment of tetracaine hydrochloride spiked into real wastewater, as described below.

Once clarified the behavior of the electrolytic systems, the decay of $0.561 \mathrm{mM}$ tetracaine in the three aqueous matrices with each of the four anodes was followed by reversed-phase HPLC for $360 \mathrm{~min}$ as maximal. In all these trials, the initial $\mathrm{pH}$ of 3.0 decayed slightly with time up to final values close to $2.7-2.8$, suggesting the formation of acidic by-products from pharmaceutical degradation. In the $0.050 \mathrm{M} \mathrm{Na}_{2} \mathrm{SO}_{4}$ solution, Fig. 1a highlights the total disappearance of the pharmaceutical using the BDD anode after about $300 \mathrm{~min}$ of treatment. In contrast, the tetracaine concentration was reduced by only $60.2 \%, 50.3 \%$ and $59.3 \%$ with $\mathrm{Pt}, \mathrm{IrO}_{2}$-based and $\mathrm{RuO}_{2}$-based anodes, respectively. Consequently, the oxidation ability of the anodes

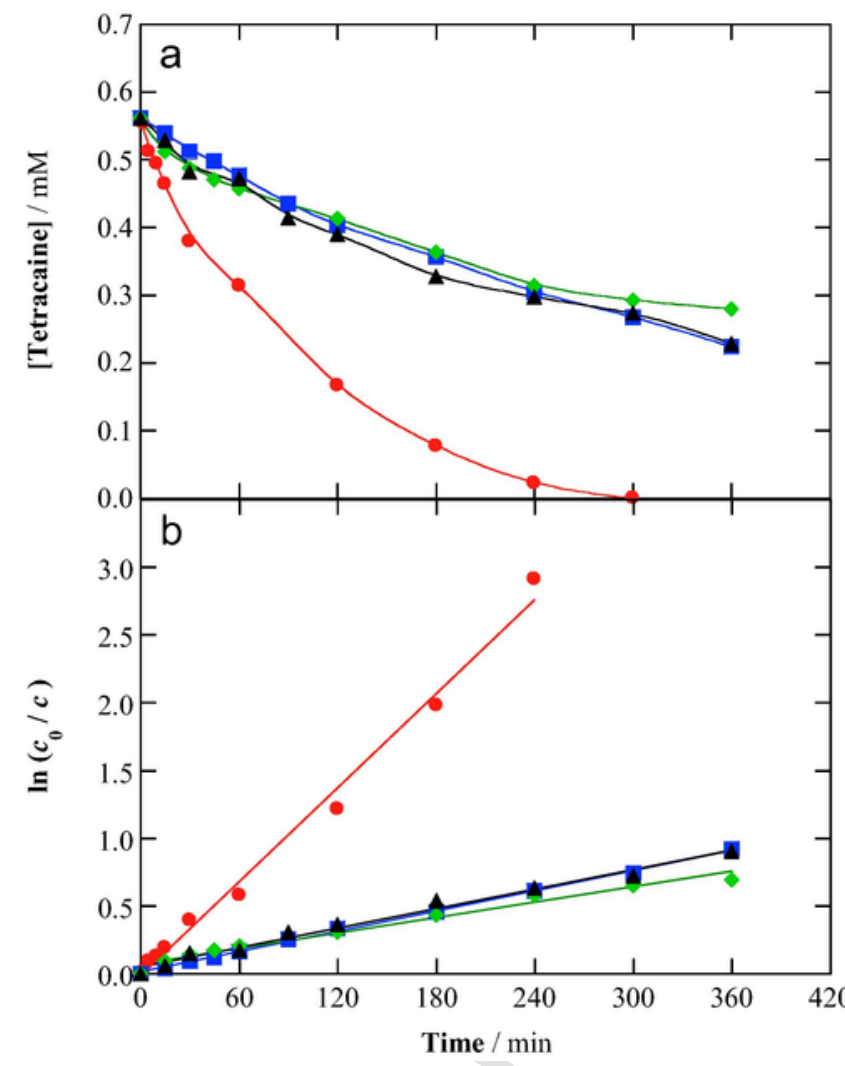

Fig. 1. (a) Concentration decay of tetracaine with electrolysis time for the electrochemical oxidation with electrogenerated $\mathrm{H}_{2} \mathrm{O}_{2}\left(\mathrm{EO}-\mathrm{H}_{2} \mathrm{O}_{2}\right)$ treatment of $150 \mathrm{~mL}$ of a $0.561 \mathrm{mM}$ tetracaine hydrochloride solution in $0.050 \mathrm{M} \mathrm{Na}_{2} \mathrm{SO}_{4}$ at $\mathrm{pH} 3.0$ and $35^{\circ} \mathrm{C}$ using a stirred tank reactor with an air-diffusion cathode at current density $(j)$ of

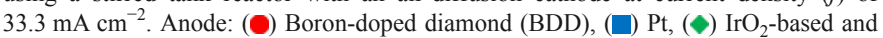
(ム) $\mathrm{RuO}_{2}$-based. The area of all electrodes was $3 \mathrm{~cm}^{2}$. (b) Pseudo-first-order kinetic analysis of the concentration decays. in this medium increased in the order: $\mathrm{IrO}_{2}$-based $<\mathrm{RuO}_{2}$-based $\sim \mathrm{Pt} \ll \mathrm{BDD}$. This trend agrees with the expected oxidative superiority of the non-active BDD anode over the other three active ones [13-15], owing to the larger generation of physisorbed $\mathrm{M}(\mathrm{OH})$ from reaction (1). A similar tendency has been reported for the degradation of $100 \mathrm{~mL}$ of $1.04 \mathrm{mM}$ methylparaben using the same kind of anodes under analogous conditions but at $j=66.7 \mathrm{~mA} \mathrm{~cm}^{-2}$ [43].

The good linear fittings obtained from the pseudo-first-order kinetic analysis of the above concentration decays are presented in Fig. 1b. Increasing apparent rate constants $\left(k_{1}\right)$ of $1.90 \times 10^{-3} \mathrm{~min}^{-1}$ (square of the correlation coefficient, $R^{2}=0.982$ ) for $\mathrm{IrO}_{2}$-based, $2.39 \times 10^{-3} \mathrm{~min}^{-1}\left(R^{2}=0.985\right)$ for $\mathrm{RuO}_{2}$-based, $2.50 \times 10^{-3} \mathrm{~min}^{-1}$ $\left(R^{2}=0.998\right)$ for Pt and $1.15 \times 10^{-2} \min ^{-1}\left(R^{2}=0.992\right)$ for BDD were obtained. As can be seen, the attack of $\operatorname{BDD}(\mathrm{OH})$ cnto tetracaine was 4.6-fold, 4.8 -fold and 6.0-fold faster than that of $\mathrm{Pt}\left({ }^{\circ} \mathrm{OH}\right), \mathrm{RuO}_{2}(\mathrm{OH})$ and $\mathrm{IrO}_{2}(\mathrm{OH})$. Hence, these three ROS are produced to a much lesser extent, which corroborates the superior oxidation ability of BDD in sulfate medium [18-20]. This behavior suggests the removal of tetracaine by a small, constant amount of physisorbed radicals during the EO- $\mathrm{H}_{2} \mathrm{O}_{2}$ treatment.

The destruction of the pharmaceutical became much quicker when the aqueous mixture contained $\mathrm{Cl}^{-}$, which can be observed in Fig. 2a in the case of the simulated matrix. Tetracaine disappeared in shorter times of about $60 \mathrm{~min}$ for $\mathrm{Pt}$ and $\mathrm{IrO}_{2}$-based, $40 \mathrm{~min}$ for $\mathrm{BDD}$ and
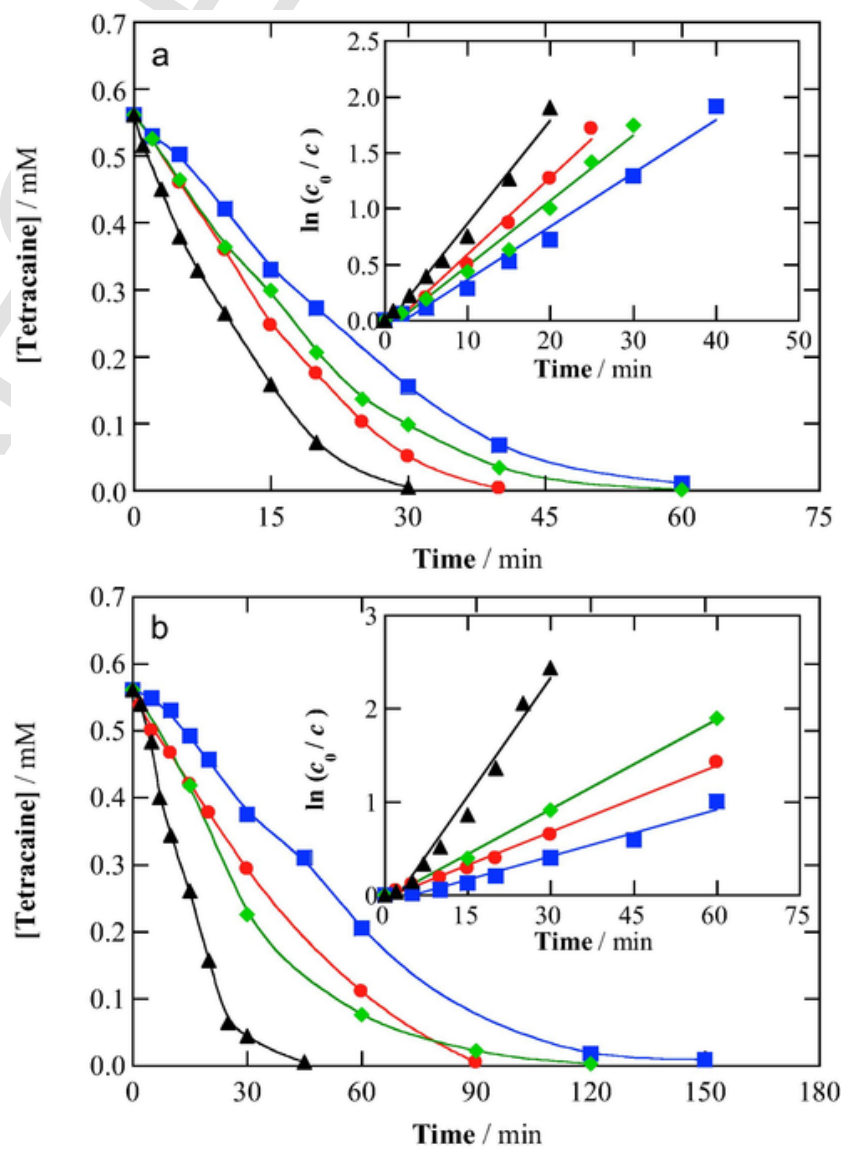

Fig. 2. Time course of tetracaine concentration for the degradation of $150 \mathrm{~mL}$ of $0.561 \mathrm{mM}$ of the pharmaceutical spiked into (a) a simulated matrix and (b) real wastewater, at $\mathrm{pH} 3.0$ and $35^{\circ} \mathrm{C}$ by EO- $\mathrm{H}_{2} \mathrm{O}_{2}$ at $j=33.3 \mathrm{~mA} \mathrm{~cm}{ }^{-2}$. Anode: (O) BDD, ( $\square$ ) Pt, (४) $\mathrm{IrO}_{2}$-based and $(\mathbf{\Delta}) \mathrm{RuO}_{2}$-based. The inset panels present the corresponding kinetic analysis considering a pseudo-first-order decay for tetracaine. 
30 min for $\mathrm{RuO}_{2}$-based, revealing that the oxidation power in this medium rose in the sequence: $\mathrm{IrO}_{2}$-based $<\mathrm{Pt}<\mathrm{BDD}<\mathrm{RuO}_{2}$-based. Accordingly, from the pseudo-first-order kinetic analysis of the concentration abatements depicted in the inset panel shown in Fig. 2a, raising $k_{1}$ values of $4.75 \times 10^{-2} \mathrm{~min}^{-1}\left(R^{2}=0.982\right), 5.82 \times 10^{-2} \mathrm{~min}^{-1}$ $\left(R^{2}=0.982\right), 6.86 \times 10^{-2} \mathrm{~min}^{-1}\left(R^{2}=0.989\right)$ and $9.22 \times 10^{-2} \mathrm{~min}^{-1}$ $\left(R^{2}=0.987\right)$ for $\mathrm{IrO}_{2}$-based, $\mathrm{Pt}, \mathrm{BDD}$ and $\mathrm{RuO}_{2}$-based, respectively, were found. The most powerful anode in this medium was that made of $\mathrm{RuO}_{2}$, which clearly outperformed the other three materials. Compared with the $k_{1}$-values determined in $0.050 \mathrm{M} \mathrm{Na}_{2} \mathrm{SO}_{4}$, the degradation rate using $\mathrm{RuO}_{2}$ presented a 38-fold enhancement, similar to that of $\mathrm{Pt}$ and $\mathrm{IrO}_{2}$-based, whereas in the case of BDD only a 5.96-fold acceleration was found. The enhanced removal of the pharmaceutical can be explained by the fast attack of active chlorine ( $\mathrm{HClO}$ at $\mathrm{pH} 3.0)$ originated from reactions (2) and (3). Our results give evidence that active chlorine was produced extensively by active anodes, pre-eminently the $\mathrm{RuO}_{2}$-based one, becoming the main oxidant for tetracaine. In contrast, active chlorine was formed to a smaller extent with BDD and thus, it competed with $\operatorname{BDD}(\mathrm{OH})$ to attack the pharmaceutical. The positive beneficial action of $\mathrm{Cl}^{-}$ions, yielding active chlorine as a powerful oxidant, has been previously reported for the $\mathrm{EO}-\mathrm{H}_{2} \mathrm{O}_{2}$ treatment of Ponceau 4R dye [19] using BDD and Pt anodes and of methylparaben [43] using the four kind of anodes.

The tetracaine abatement became slower when it was spiked into the real wastewater effluent, as can be seen in Fig. $2 b$ and in the corresponding kinetic analysis of the inset panel. Total removal was achieved after 150, 120, 90 and 45 min using $\mathrm{IrO}_{2}$-based, Pt, BDD and $\mathrm{RuO}_{2}$-based anodes, with $k_{1}$-values of $1.67 \times 10^{-2} \mathrm{~min}^{-1}\left(R^{2}=0.980\right)$, $3.19 \times 10^{-2} \mathrm{~min}^{-1}\left(R^{2}=0.998\right), 2.36 \times 10^{-2} \mathrm{~min}^{-1}\left(R^{2}=0.995\right)$ and $8.45 \times 10^{-2} \mathrm{~min}^{-1}\left(R^{2}=0.981\right)$. Although the $\mathrm{RuO}_{2}$-based anode was again the most powerful one, its oxidation ability dropped compared with that found in the simulated matrix. Larger decreases were found for the other anodes, particularly for BDD, whose oxidation power was one third of the previous one. The slower destruction of tetracaine in the real wastewater can be ascribed to the parallel oxidation of NOM by generated $\mathrm{M}(\mathrm{OH})$ and active chlorine. This competition was less significant for the $\mathrm{RuO}_{2}$-based anode, probably because of its greater ability to produce active chlorine, but it was comparatively important for the BDD anode, suggesting a dramatic scavenging effect of $\mathrm{NOM}$ on $\operatorname{BDD}(\mathrm{OH})$ with the consequently lower availability for the pharmaceutical.

\subsection{Mineralization of tetracaine hydrochloride solutions}

Once elucidated the effect of the anodes and aqueous matrices on pharmaceutical decay, the mineralization of solutions with $0.561 \mathrm{mM}$ tetracaine hydrochloride at $\mathrm{pH} 3.0$ and $35^{\circ} \mathrm{C}$ was comparatively investigated for the different electrolytic systems at $j=33.3 \mathrm{~mA} \mathrm{~cm}^{-2}$ for $360 \mathrm{~min}$. The normalized TOC removal with electrolysis time for such trials is presented in Fig. 3. Worth noting, one can observe that the most effective anode for mineralization was always BDD, regardless of the medium used.

Fig. 3a highlights that in $0.050 \mathrm{M} \mathrm{Na}_{2} \mathrm{SO}_{4}$, TOC was reduced by $52.9 \%$ at the end of $\mathrm{EO}-\mathrm{H}_{2} \mathrm{O}_{2}$ treatment with $\mathrm{BDD}$, whereas $<7 \%$ of the organic load was mineralized using $\mathrm{Pt}, \mathrm{IrO}_{2}$-based or $\mathrm{RuO}_{2}$-based anodes. This means that the strongest ROS generated under these conditions, i.e., $\mathrm{BDD}(\mathrm{OH})$, was powerful enough not only to remove the parent drug in $300 \mathrm{~min}$ (see Fig. 1a), but also to mineralize a large amount of its by-products. In contrast, generated $\mathrm{Pt}\left({ }^{\circ} \mathrm{OH}\right), \mathrm{IrO}_{2}(\mathrm{OH})$ and $\mathrm{RuO}_{2}(\mathrm{OH})$ turned out to be very inefficient to transform the intermediates into $\mathrm{CO}_{2}$. This is not surprising based on the very slow

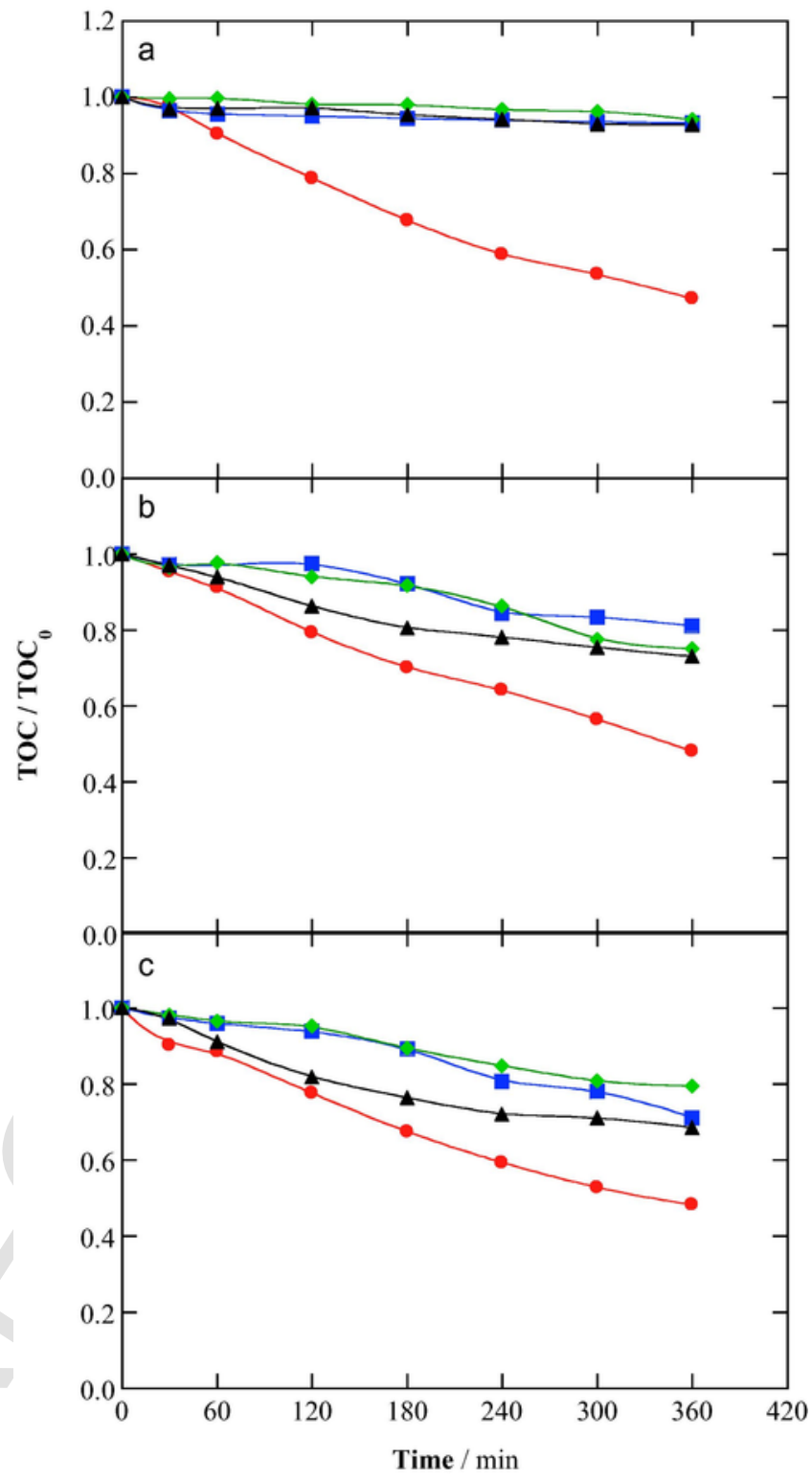

Fig. 3. Normalized TOC removal with electrolysis time for the EO- $\mathrm{H}_{2} \mathrm{O}_{2}$ assays made under the conditions described in: (a) Fig. 1a, (b) Fig. 2a and (c) Fig. 2b. Anode: (O) $\mathrm{BDD},(\square) \mathrm{Pt},(\bullet) \mathrm{IrO}_{2}$-based and $(\boldsymbol{\bullet}) \mathrm{RuO}_{2}$-based.

destruction of the pharmaceutical with the latter three anodes (see Fig. 1a).

In the simulated matrix (Fig. 3b), the mineralization ability of BDD was slightly lower, achieving $52.0 \%$ of TOC decay. Conversely, the mineralization degree was strongly upgraded with the three active anodes, which led to a TOC reduction of $19.1 \%(\mathrm{Pt}), 25.0 \%$ ( $\mathrm{IrO}_{2}$-based) and $27.2 \%\left(\mathrm{RuO}_{2}\right.$-based). Despite the clear superiority of the $\mathrm{RuO}_{2}$-based anode to destroy tetracaine (see Fig. 2a) as result of the quicker attack of the greater amounts of generated active chlorine, the by-products formed, probably including chloroderivatives $[9,11]$, became so recalcitrant that they were poorly mineralized. The same behavior can be valid for $\mathrm{Pt}$ and $\mathrm{IrO}_{2}$-based as well, since they also generated active chlorine as the main oxidizing species in the simulated matrix. The greater mineralization achieved with BDD can then be accounted for by two factors: (i) the smaller formation of active chlorine species, with subsequent accumulation of a lower amount of 
chloroderivatives and, more important, (ii) the larger ability of $\operatorname{BDD}(\mathrm{OH})$ to mineralize the intermediates formed.

The different reactivity of oxidizing species can also be observed in Fig. 3c, where the TOC of the electrolyzed pharmaceutical solution in real wastewater was finally reduced by $51.8 \%, 28.9 \%, 22.6 \%$ and $31.5 \%$ using $\mathrm{BDD}, \mathrm{Pt}, \mathrm{IrO}_{2}$-based and $\mathrm{RuO}_{2}$-based anodes, respectively. Note that the initial TOC of $0.561 \mathrm{mM}$ tetracaine hydrochloride in the real wastewater was $112 \mathrm{mg} \mathrm{L}^{-1}$, being a bit higher than $100 \mathrm{mg} \mathrm{L}^{-1}$ TOC in the simulated matrix due to the existence of NOM in the former matrix. One can then conclude that a larger amount of organic matter was mineralized in the real water samples regardless of the anode (except for the $\mathrm{IrO}_{2}$-based one) because of the competitive degradation of NOM and tetracaine by $\mathrm{M}\left({ }^{\circ} \mathrm{OH}\right)$ and active chlorine. Again, the oxidation power of physisorbed $\operatorname{BDD}(\mathrm{OH})$ became greater than that of active chlorine and hence, EO- $\mathrm{H}_{2} \mathrm{O}_{2}$ with $\mathrm{BDD}$ was the most powerful decontamination treatment for solutions prepared in real wastewater.

\subsection{Fate of inorganic ions and mineralization current efficiency}

The evolution of TN and inorganic ions present in the water matrices and/or released along tetracaine cleavage was analyzed for the EO- $\mathrm{H}_{2} \mathrm{O}_{2}$ treatments after $360 \mathrm{~min}$ in $0.050 \mathrm{M} \mathrm{Na}_{2} \mathrm{SO}_{4}$ and in the simulated matrix, thus avoiding the expected interferences from NOM destruction in the real wastewater. In $0.050 \mathrm{M} \mathrm{Na}_{2} \mathrm{SO}_{4}$, only the behavior of the most potent anode (BDD) was investigated. It was found that the initial $\mathrm{SO}_{4}{ }^{2-}$ content remained practically constant during the electrolysis, whereas the initial $\mathrm{Cl}^{-}$concentration (from the hydrochloride) decayed from $0.561 \mathrm{mM}$ to $0.222 \mathrm{mM}$, with a final amount of $6.39 \mathrm{mg} \mathrm{L}^{-1}$ of active chlorine $(0.12 \mathrm{mM})$. The very slow removal of tetracaine in this medium using the three active anodes (see Fig. 1) suggests a really poor contribution of active chlorine compared to $\mathrm{M}(\mathrm{OH})$ and thus, it was correct to omit the role of $\mathrm{Cl}^{-}$in this medium in sections 3.1 and 3.2. At the end of $\mathrm{EO}-\mathrm{H}_{2} \mathrm{O}_{2}, 0.27 \mathrm{mM}$ $\mathrm{NO}_{3}{ }^{-}(24.1 \%$ of initial $\mathrm{N})$ and no $\mathrm{NH}_{4}^{+}$or $\mathrm{NO}_{2}^{-}$ions were found. Moreover, the TN value dropped from 1.12 to $0.96 \mathrm{mM}$. These findings indicate that $0.69 \mathrm{mM}(61.6 \%)$ of the initial $\mathrm{N}$ of tetracaine still remained in the final solution as highly recalcitrant $\mathrm{N}$-derivatives, with a loss of $14.3 \%$ of initial $\mathrm{N}$ probably due to the release of volatile $\mathrm{N}_{2}$ and/or $\mathrm{N}_{\mathrm{x}} \mathrm{O}_{\mathrm{y}}$, as found for other nitrogenated aromatics [12,37].

Table 1 summarizes the results obtained for the initial solution and after $360 \mathrm{~min}$ of electrolysis using the four anodes tested in the simulated matrix. As can be seen, the TN dropped in all cases during the EO- $\mathrm{H}_{2} \mathrm{O}_{2}$ treatment due to the loss of volatile by-products, primordially for the $\mathrm{RuO}_{2}$-based anode (release of $65.6 \%$ of initial $\mathrm{N}$ ), which can be plausibly ascribed to the formation of chloramines by reaction of the large amounts of generated active chlorine with $\mathrm{NH}_{4}^{+}$

Table 1

Total nitrogen, active chlorine and inorganic ions concentration before and after $360 \mathrm{~min}$ of $\mathrm{EO}-\mathrm{H}_{2} \mathrm{O}_{2}$ treatment of $150 \mathrm{~mL}$ of a simulated aqueous matrix containing $0.561 \mathrm{mM}$ tetracaine hydrochloride at $\mathrm{pH} 3.0$ and $35^{\circ} \mathrm{C}$, using different anodes and an air-diffusion cathode at $j=33.3 \mathrm{~mA} \mathrm{~cm}^{-2}$.

\begin{tabular}{llllll}
\hline & $\begin{array}{l}\text { Before } \\
\text { electrolysis }\end{array}$ & $\begin{array}{l}\mathrm{BDD} \\
\text { (end) }\end{array}$ & $\begin{array}{l}\mathrm{Pt} \\
\text { (end) }\end{array}$ & $\begin{array}{l}\mathrm{IrO}_{2^{-}} \\
\text {based } \\
\text { (end) }\end{array}$ & $\begin{array}{l}\mathrm{RuO}_{2^{-}} \\
\text {based } \\
\text { (end) }\end{array}$ \\
\hline $\mathrm{TN}(\mathrm{mM})$ & 2.62 & 2.06 & 2.09 & 2.27 & 0.90 \\
$\mathrm{NO}_{3}^{-}(\mathrm{mM})$ & 0.020 & 0.034 & 0.044 & 0.060 & 0.091 \\
$\mathrm{SO}_{4}{ }^{-2}(\mathrm{mM})$ & 1.51 & 1.20 & 1.50 & 1.51 & 1.40 \\
$\mathrm{Cl}^{-}(\mathrm{mM})$ & 14.82 & 2.38 & 10.63 & 14.45 & 7.51 \\
$\mathrm{ClO}_{3}^{-}(\mathrm{mM})$ & - & 6.64 & 2.37 & 0.02 & 0.38 \\
$\mathrm{ClO}_{4}^{-}(\mathrm{mM})$ & 0.55 & 1.94 & 1.00 & 0.73 & 0.72 \\
$\left.\mathrm{Active} \mathrm{chlorine}_{(m g ~ L}{ }^{-1}\right)$ & - & 2.07 & 1.57 & 3.14 & 65.25 \\
\hline
\end{tabular}

contained in the matrix. Table 1 also shows the release of $\mathrm{NO}_{3}{ }^{-}$from tetracaine under all conditions, with increasing contents of 0.014 , $0.024,0.040$ and $0.071 \mathrm{mM}$ using $\mathrm{BDD}, \mathrm{Pt}, \mathrm{IrO}_{2}$-based and $\mathrm{RuO}_{2}$-based anodes, respectively. This trend is indicative of the presence of much lower amounts of $N$-derivatives in the final solutions using the three active anodes compared to BDD, which can be related to the preferential destrustion of these by-products by active chlorine, rather than by $\mathrm{BDD}(\mathrm{OH})$. In contrast, the initial $\mathrm{SO}_{4}{ }^{2-}$ decreased much more largely for BDD. This can be explained by its anodic oxidation to peroxodisulfate $\left(\mathrm{S}_{2} \mathrm{O}_{8}{ }^{2-}\right)$, favored at the BDD surface as follows [9,13]:

$$
2 \mathrm{SO}_{4}^{2-} \rightarrow \mathrm{S}_{2} \mathrm{O}_{8}^{2-}+2 \mathrm{e}^{-}
$$

The fate of detected chlorinated ions is also remarkable. From Table 1, one can infer that the initial $\mathrm{Cl}^{-}$was much more rapidly removed using BDD, which could seem contradictory from the results reported in Figs. 2 and 3 that have been explained on the basis of the large effectiveness of generated active chlorine formed with the three active anodes. The larger destruction of $\mathrm{Cl}^{-}$with BDD can then be ascribed to the quicker consecutive oxidation of active chlorine to $\mathrm{ClO}_{3}{ }^{-}$and $\mathrm{ClO}_{4}{ }^{-}$, according to reactions (9)(11) $[37,43]$. Table 1 shows a much greater production of the two latter ions using BDD. Furthermore, the remaining active chlorine rose in the sequence: $\mathrm{Pt}<\mathrm{BDD}<\mathrm{IrO}_{2}$-based $\ll \mathrm{RuO}_{2}$-based, i.e., the same order followed to degrade tetracaine in Fig. 2a, which corroborates the pre-eminent oxidative role of this species in $\mathrm{Cl}^{-}$-containing matrices. Note the active chlorine concentration as high as $65.25 \mathrm{mg} \mathrm{L}^{-1}$ found with the $\mathrm{RuO}_{2}$-based anode, whereas it was $<3.5 \mathrm{mg} \mathrm{L}^{-1}$ with the other ones. This agrees with the expected greater ability of the former anode to oxidize $\mathrm{Cl}^{-}$, pointed out above, with low formation of $\mathrm{ClO}_{3}{ }^{-}$and $\mathrm{ClO}_{4}{ }^{-}[13,43]$.

$$
\begin{aligned}
& \mathrm{HClO}+\mathrm{H}_{2} \mathrm{O} \rightarrow \mathrm{ClO}_{2}^{-}+3 \mathrm{H}^{+}+2 \mathrm{e}^{-} \\
& \mathrm{ClO}_{2}^{-}+\mathrm{H}_{2} \mathrm{O} \rightarrow \mathrm{ClO}_{3}^{-}+2 \mathrm{H}^{+}+2 \mathrm{e}^{-} \\
& \mathrm{ClO}_{3}^{-}+\mathrm{H}_{2} \mathrm{O} \rightarrow \mathrm{ClO}_{4}^{-}+2 \mathrm{H}^{+}+2 \mathrm{e}^{-}
\end{aligned}
$$

Based on the aforementioned findings, the theoretical mineralization reaction of the protonated form of tetracaine, the species present in each matrix, can be written as reaction (12), with formation of $\mathrm{CO}_{2}$ and $\mathrm{NO}_{3}{ }^{-}$and the consumption of 90 electrons $(n)$ :

$$
\begin{aligned}
\mathrm{C}_{15} \mathrm{H}_{25} \mathrm{~N}_{2} \mathrm{O}_{2}^{+}+34 \mathrm{H}_{2} \mathrm{O} \rightarrow & 15 \mathrm{CO}_{2}+2 \mathrm{NO}_{3}^{-} \\
& +93 \mathrm{H}^{+}+90 \mathrm{e}^{-}
\end{aligned}
$$

The mineralization current efficiency (MCE) for each trial at applied current $I(=0.100 \mathrm{~A})$ and given electrolysis time $t$ (in $\mathrm{h})$ was then estimated from Eq. (13) [27,33]:

$$
\% \mathrm{MCE}=\frac{n F V_{s} \Delta(\mathrm{TOC})_{\exp }}{4.32 \times 10^{7} \mathrm{mIt}} \times 100
$$

where $F$ is the Faraday constant $\left(96,487 \mathrm{C} \mathrm{mol}^{-1}\right), V_{\mathrm{s}}$ is the solution 
volume $(=0.150 \mathrm{~L}), \Delta(\text { TOC })_{\exp }$ is the experimental TOC abatement (in $\mathrm{mg} \mathrm{L} \mathrm{L}^{-1}$ ), $4.32 \times 10^{7}$ is a conversion factor $\left(3600 \mathrm{~s} \mathrm{~h}^{-1} \times 12,000 \mathrm{mg} \mathrm{C} \mathrm{mol}^{-1}\right)$ and $m$ is the number of carbon atoms of tetracaine $(=15)$.

Fig. 4a and b depict the MCE values calculated from Eq. (13) for the assays shown in Fig. 3a and b, respectively. In both cases, the current efficiency for BDD fluctuates between $17.7 \%$ and near $21 \%$ at $60-360 \mathrm{~min}$ of electrolysis, being slightly higher in the $0.050 \mathrm{M}$ $\mathrm{Na}_{2} \mathrm{SO}_{4}$ compared with the simulated matrix. This means that organic pollutants were mineralized at practically constant rate during each run, independently of the main oxidizing species, which was $\operatorname{BDD}(\mathrm{OH})$ in the former matrix and its combination with active chlorine in the second one. Conversely, the MCE values using the three active anodes changed strongly depending on the absence or presence of $\mathrm{Cl}^{-}$. In $0.050 \mathrm{M} \mathrm{Na}_{2} \mathrm{SO}_{4}$, owing to a low oxidation ability of their physisorbed $\mathrm{M}\left({ }^{\circ} \mathrm{OH}\right)$, the current efficiency was very small attaining final values of about $2 \%$ for the three anodes. However, the current efficiency was much greater in the simulated matrix thanks to the additional oxidation power of generated active chlorine, and it varied between $5.9 \%$ and $7.9 \%$ using Pt, $6.0 \%-9.0 \%$ with $\mathrm{IrO}_{2}$-based and between $9.0 \%-13.8 \%$ with a $\mathrm{RuO}_{2}$-based anode, suggesting an almost constant mineralization rate in this medium.

The above results allow concluding that the BDD/air-diffusion cell was the best system to decontaminate the sulfate solution, the simulated matrix and the real wastewater containing tetracaine. This is due to the great mineralization power of $\operatorname{BDD}(\mathrm{OH})$ alone or in combination with active chlorine, although the process became slightly less efficient in the presence of $\mathrm{Cl}^{-}$because of the formation of persistent chloroderivatives, as discussed below.

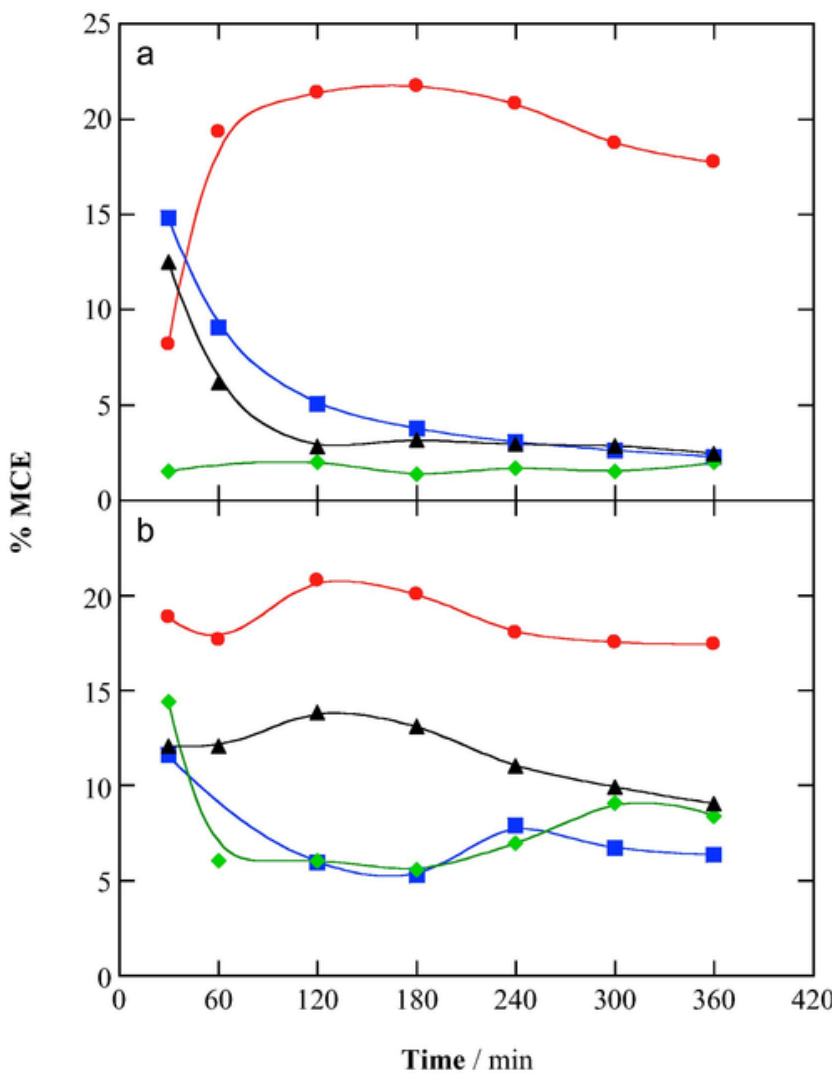

Fig. 4. Mineralization current efficiency calculated from Eq. (13) vs. electrolysis time for the profiles presented in: (a) Fig. 3a and (b) Fig. 3b.

\subsection{Detection of by-products and toxicity assessment}

Table 2 summarizes the aromatic by-products identified by GC-MS for tetracaine (1) in $0.050 \mathrm{M} \mathrm{Na}_{2} \mathrm{SO}_{4}$ and in the simulated matrix at $\mathrm{pH} 3.0$ upon degradation by the best EO- $\mathrm{H}_{2} \mathrm{O}_{2}$ treatment, i.e., using BDD anode at $j=33.3 \mathrm{~mA} \mathrm{~cm}^{-2}$. Up to four intermediates (compounds $\mathbf{2 a}-\mathbf{5 a}$ ) were detected in the former medium. Compound 2a is originated from the loss of both, the butyl group of the secondary amine of $\mathbf{1}$ and a dimethylamine side group. Further release of a side methyl group of the ethyl ester yields compound 3a, whose $-\mathrm{NH}_{2}$ group can be subsequently oxidized to $-\mathrm{NO}_{2}$ yielding compound $\mathbf{4 a}$. On the other hand, the loss of the ethyl group of the secondary amine of $\mathbf{1}$ and the cleavage of the carboxylate one leads to compound 5a. All these aromatics came from the successive attack of the preferential oxidant $\operatorname{BDD}(\mathrm{OH})$ onto 1 , but they were not found during the EO- $\mathrm{H}_{2} \mathrm{O}_{2}$ treatment in the simulated matrix. Under these conditions, Table 2 shows the detection of only the dichloroaromatic $\mathbf{2} \mathbf{b}$, thus corroborating the destruction of $\mathbf{1}$ by means of active chlorine formed from the anodic oxidation of $\mathrm{Cl}^{-}$of the medium and the generation of recalcitrant chloroderivatives, as proposed above.

Along the degradation of aromatic pollutants by $\mathrm{EO}-\mathrm{H}_{2} \mathrm{O}_{2}$, the cleavage of the benzene rings of aromatic intermediates to yield final short-chain linear aliphatic carboxylic acids is expected [9-12,40-43]. This behavior was confirmed for tetracaine from ion-exclusion HPLC analysis of $0.561 \mathrm{mM}$ drug solutions electrolyzed using the potent BDD/air-diffusion cell. Fig. 5 shows that, in $0.050 \mathrm{M} \mathrm{Na}_{2} \mathrm{SO}_{4}$, oxalic acid was gradually accumulated up to attain a concentration of $0.025 \mathrm{mM}$, whereas very small contents $<6.0 \times 10^{-4} \mathrm{mM}$ fumaric acid were also detected. It is well known that fumaric acid is oxidized to oxalic acid as ultimate by-product, which is slowly and directly transformed into $\mathrm{CO}_{2}$ at the BDD surface $[11,12]$. Note that the final concentrations of both acids only accounted for $0.6 \mathrm{mg} \mathrm{L}^{-1}(1.3 \%)$ out of the $47.1 \mathrm{mg} \mathrm{L}^{-1}$ TOC of the final electrolyzed solution (see Fig. 3a), indicating that a great deal of remaining organic matter corresponded to other unidentified compounds, including $N$-derivatives, as suggested above. For the simulated matrix, Fig. 5 only highlights the presence of oxalic acid, with contents $<3.5 \times 10^{-3} \mathrm{mM}$ $\left(<0.1 \mathrm{mg} \mathrm{L}^{-1}\right.$ TOC). Such a low amount suggests that chloroderivatives originated from this matrix were rather oxidized to short-chain by-products different from simple, non-chlorinated carboxylic acids to be mineralized to $\mathrm{CO}_{2}$.

The relative toxicity of generated intermediates was assessed from the change in $\mathrm{EC}_{50}$ of solutions degraded by $\mathrm{EO}-\mathrm{H}_{2} \mathrm{O}_{2}$ with a $\mathrm{BDD}$ anode. As can be seen in Fig. 6, the value of this parameter for $0.561 \mathrm{mM}$ tetracaine hydrochloride in the sulfate solution was $2.35 \mathrm{mg} \mathrm{L}^{-1}$, being slightly lower $\left(1.46 \mathrm{mg} \mathrm{L}^{-1}\right)$ in the real wastewater due to some toxic compounds related to its NOM content. These $\mathrm{EC}_{50}$ values grew up to 7.05 and $2.68 \mathrm{mg} \mathrm{L}^{-1}$ at the end of electrolysis, respectively, suggesting a very low loss of toxicity of both treated matrices. To better clarify this behavior, the same matrices but with smaller content of $0.056 \mathrm{mM}$ tetracaine hydrochloride $\left(\sim 10 \mathrm{mg} \mathrm{L}^{-1} \mathrm{TOC}\right)$ were electrolyzed under analogous conditions for $360 \mathrm{~min}$, achieving $46.1 \%$ and $62.7 \%$ of mineralization. Fig. 6 depicts a dramatic drop of the starting $\mathrm{EC}_{50}=20.35 \mathrm{mg} \mathrm{L}^{-1}$ of the $0.056 \mathrm{mM}$ tetracaine hydrochloride in $0.050 \mathrm{M} \mathrm{Na}_{2} \mathrm{SO}_{4}$ solution to $4.78 \mathrm{mg} \mathrm{L}^{-1}$ at $180 \mathrm{~min}$, followed by a slight increase to $6.30 \mathrm{mg} \mathrm{L}^{-1}$ at $360 \mathrm{~min}$. Similarly, the lower $\mathrm{EC}_{50}$ of the real wastewater $\left(17.73 \mathrm{mg} \mathrm{L}^{-1}\right)$ decayed more largely, up to $0.65 \mathrm{mg} \mathrm{L}^{-1}$ at $240 \mathrm{~min}$, and attained a final value of $2.08 \mathrm{mg} \mathrm{L}^{-1}$. These findings indicate that the by-products formed during both EO- $\mathrm{H}_{2} \mathrm{O}_{2}$ treatments were more toxic than the parent drug, showing higher toxicity in the real waste- 
Table 2

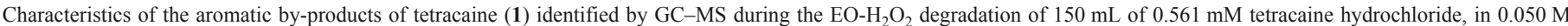
$\mathrm{Na}_{2} \mathrm{SO}_{4}$ (compounds $\mathbf{2 a - 5 a}$ ) or in a simulated matrix (compound $\mathbf{2 b}$ ), at pH 3.0 and $35^{\circ} \mathrm{C}$ with a BDD/air-diffusion cell at $j=33.3 \mathrm{~mA} \mathrm{~cm}{ }^{-2}$.

\begin{tabular}{|c|c|c|c|c|}
\hline Reference & Compound & Molecular structure & $t_{\mathrm{r}}^{\mathrm{a}}(\min )$ & Main fragmentation ions $(\mathrm{m} / \mathrm{z})$ \\
\hline 1 & Tetracaine & & 41.1 & $210,139,71,58$ \\
\hline $2 a$ & 4-Aminobenzoic acid ethyl ester & & 7.23 & $165,149,135,120$ \\
\hline $3 \mathbf{a}$ & 4-Aminobenzoic acid methyl ester & & 7.60 & $151,133,119,105,77$ \\
\hline $4 a$ & 4-Nitrobenzoic acid methyl ester & & 33.65 & $181,163,149,133,104,92,76$ \\
\hline $5 a$ & 4-Ethylamino benzaldehyde & & 27.04 & $147,135,107,94,77$ \\
\hline $2 \mathbf{b}$ & 4-Amino-2,5-dichlorobenzoic acid methyl ester & & 29.05 & $219,188,160,124$ \\
\hline
\end{tabular}

\footnotetext{
${ }^{a}$ Retention time.
}

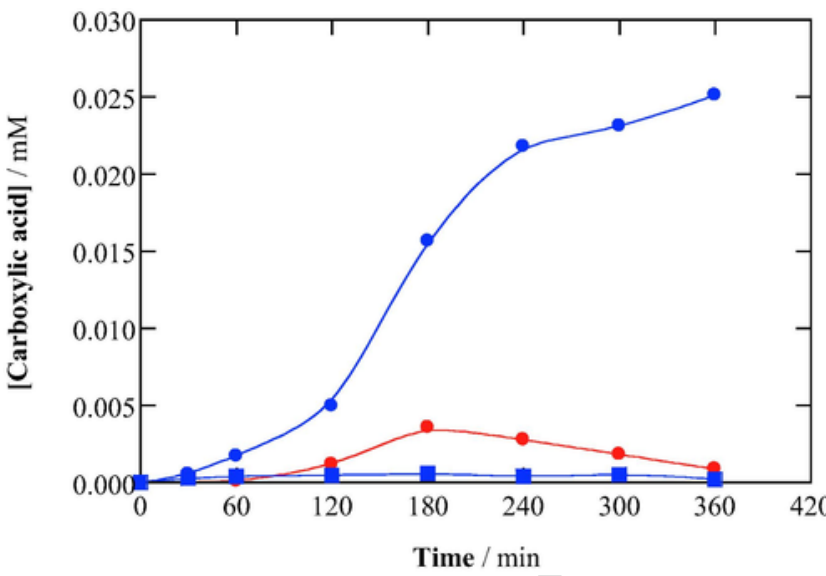

Fig. 5. Evolution of the concentration of $(\mathbf{O}, \mathbf{O})$ oxalic and $(\square)$ fumaric acids detected during the $\mathrm{EO}-\mathrm{H}_{2} \mathrm{O}_{2}$ treatment of $150 \mathrm{~mL}$ of $0.561 \mathrm{mM}$ tetracaine hydrochloride in: ( , $0.050 \mathrm{M} \mathrm{Na}_{2} \mathrm{SO}_{4}$ and (O) simulated matrix, at pH 3.0 and $35^{\circ} \mathrm{C}$ using a BDD/ air-diffusion cell at $j=33.3 \mathrm{~mA} \mathrm{~cm}{ }^{-2}$.

water because of the production of a large amount of chloroderivatives. Therefore, longer electrochemical treatments would be required in case of implementation of the $\mathrm{EO}-\mathrm{H}_{2} \mathrm{O}_{2}$ process, aiming to ensure complete detoxification.

\section{Conclusions}

The removal of tetracaine in $0.050 \mathrm{M} \mathrm{Na} \mathrm{NO}_{4}$ solution by EO- $\mathrm{H}_{2} \mathrm{O}_{2}$ was much faster using $\mathrm{BDD}$ than active anodes like Pt,

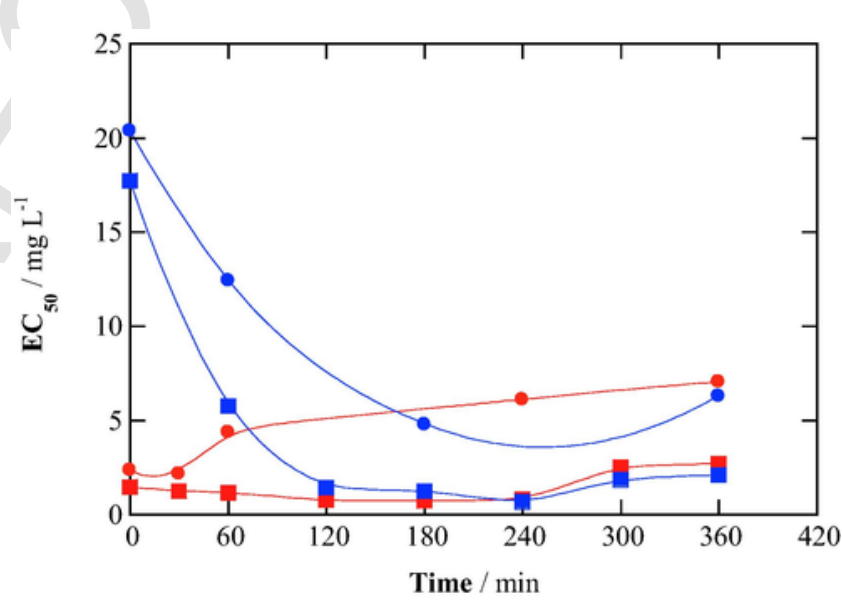

Fig. 6. Time course of $\mathrm{EC}_{50}$ determined from the abatement at $15 \mathrm{~min}$ of the bioluminescence of the marine bacteria Vibrio fischeri during the EO- $\mathrm{H}_{2} \mathrm{O}_{2}$ degradation of $150 \mathrm{~mL}$ of $(\mathbf{O}, 0.056$ and $(\mathbf{O}, \square) 0.561 \mathrm{mM}$ tetracaine hydrochloride in: (

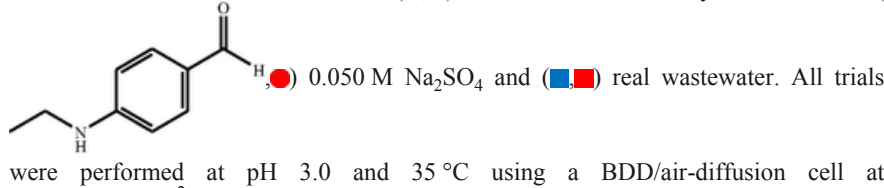
were performed at $\mathrm{pH} 3.0$ and $35^{\circ} \mathrm{C}$ using a BDD/air-diffusion cell at $j=33.3 \mathrm{~mA} \mathrm{~cm}^{-2}$.

$\mathrm{IrO}_{2}$-based and $\mathrm{RuO}_{2}$-based ones, due to the greater oxidation ability of $\operatorname{BDD}(\mathrm{OH})$ compared to that of their $\mathrm{M}\left({ }^{\circ} \mathrm{OH}\right)$. In contrast, quicker pharmaceutical decay was found using the $\mathrm{RuO}_{2}$-based anode in the simulated matrix and the real wastewater, because this material pro- 
duces greater amounts of active chlorine that attack very rapidly the parent molecule. Regarding the mineralization of tetracaine solutions, the BDD/air-diffusion cell became the best system regardless of the matrix, leading to about $52 \%$ of TOC removal after $360 \mathrm{~min}$ at $j=33.3 \mathrm{~mA} \mathrm{~cm}^{-2}$. This means that $\operatorname{BDD}\left({ }^{\circ} \mathrm{OH}\right)$ is able to gradually mineralize the chlorinated by-products that are typical in $\mathrm{Cl}^{-}$-containing matrices. The initial $\mathrm{N}$ of tetracaine was transformed into $\mathrm{NO}_{3}{ }^{-}, N$-derivatives and volatile by-products, whereas the $\mathrm{Cl}^{-}$ion was mainly converted to $\mathrm{ClO}_{3}{ }^{-}$and $\mathrm{ClO}_{4}{ }^{-}$ions with $\mathrm{BDD}$ and to active chlorine with the active anodes, especially with the $\mathrm{RuO}_{2}$-base one. $\mathrm{Up}$ to four aromatic intermediates were detected in $0.050 \mathrm{M} \mathrm{Na}_{2} \mathrm{SO}_{4}$, whereas in the simulated matrix a dichloroaromatic was identified, corroborating the formation of chloroderivatives under real conditions. This agrees with the significant decrease of $\mathrm{EC}_{50}$ values found in all the trials performed in this work.

\section{Acknowledgements}

Financial support from project CTQ2016-78616-R (AEI/FEDER, EU) and from the FPI grant awarded to C. Ridruejo (MINECO, Spain) is acknowledged. C. Salazar thanks FONDECYT Postdoctoral Grant 3150253 (Chile).

\section{References}

[1] I. Sirés, E. Brillas, Remediation of water pollution caused by pharmaceutical residues based on electrochemical separation and degradation technologies: a review, Environ. Int. 40 (2012) 212-229.

[2] L. Feng, E.D. Van Hullebusch, M.A. Rodrigo, G. Esposito, M.A. Oturan, Removal of residual anti-inflammatory and analgesic pharmaceuticals from aqueous systems by electrochemical advanced oxidation processes. A review, Chem. Eng. J. 228 (2013) 944-964.

[3] J. Rivera-Utrilla, M. Sánchez-Polo, M.A. Ferro-García, G. Prados-Joya, R. Ocampo-Pérez, Pharmaceuticals as emerging contaminants and their removal from water. A review, Chemosphere 93 (2013) 1268-1287.

[4] O. Golovko, V. Kumar, G. Fedorova, T. Randak, R. Grabic, Seasonal changes in antibiotics, antidepressants/psychiatric drugs, antihistamines and lipid regulators in a wastewater treatment plant, Chemosphere 111 (2014) 418-426.

[5] F. Al-Otaibi, E. Ghazaly, A. Johnston, D. Perrett, Development of HPLC-UV method for rapid and sensitive analysis of topically applied tetracaine: its comparison with a CZE method, Biomed. Chromatogr. 28 (2014) 826-830.

[6] J.P. Shubha, Puttaswamy, Oxidation of tetracaine hydrochloride by chloramine-b in acid medium: kinetic modeling, Adv. Phys. Chem. (2014). Article ID 238984,8 pages.

[7] J. Fick, R.H. Lindberg, M. Tysklind, D.G.J. Larsson, Predicted critical environmental concentrations for 500 pharmaceuticals, Regul. Toxicol. Pharmacol. 58 (2010) 516-523.

[8] B.I. Escher, R. Baumgartner, M. Koller, K. Treyer, J. Lienert, C.S. McArdell, Environmental toxicology and risk assessment of pharmaceuticals from hospital wastewater, Water Res. 45 (2011) 75-92.

[9] I. Sirés, E. Brillas, M.A. Oturan, M.A. Rodrigo, M. Panizza, Electrochemical advanced oxidation processes: today and tomorrow. A review, Environ. Sci. Pollut. Res. 21 (2014) 8336-8367.

[10] S. Vasudevan, M.A. Oturan, Electrochemistry: as cause and cure in water pollution-an overview, Environ. Chem. Lett. 12 (2014) 97-108.

[11] C.A. Martínez-Huitle, M.A. Rodrigo, I. Sirés, O. Scialdone, Single and coupled electrochemical processes and reactors for the abatement of organic water pollutants: a critical review, Chem. Rev. 115 (2015) 13362-13407.

[12] F.C. Moreira, R.A.R. Boaventura, E. Brillas, V.J.P. Vilar, Electrochemical advanced oxidation processes: a review on their application to synthetic and real wastewaters, Appl. Catal. B 202 (2017) 217-261

[13] M. Panizza, G. Cerisola, Direct and mediated anodic oxidation of organic pollutants, Chem. Rev. 109 (2009) 6541-6569.

[14] B. Boye, P.A. Michaud, B. Marselli, M.M. Dieng, E. Brillas, C. Comninellis, Anodic oxidation of 4-chlorophenoxyacetic acid on synthetic boron-doped diamond electrodes, New Diamond Front. Carbon Technol. 12 (2002) 63-72.

[15] B. Marselli, J. Garcia-Gomez, P.A. Michaud, M.A. Rodrigo, C. Comninellis, Electrogeneration of hydroxyl radicals on boron-doped diamond electrodes, J. Electrochem. Soc. 150 (2003) D79-D83.

[16] J. Ribeiro, F.L.S. Purgato, K.B. Kokoh, J.-M. Léger, A.R. De Andrade, Application of $\mathrm{Ti} / \mathrm{RuO}_{2}-\mathrm{Ta}_{2} \mathrm{O}_{5}$ electrodes in the electrooxidation of ethanol and de- rivants: reactivity versus electrocatalytic efficiency, Electrochim. Acta 53 (2008) 7845-7851.

[17] O. Scialdone, S. Randazzo, A. Galia, G. Filardo, Electrochemical oxidation of organics at metal oxide electrode: the incineration of oxalic acid at $\mathrm{IrO}_{2}-\mathrm{Ta}_{2} \mathrm{O}_{5}$ (DSA-O $)_{2}$ anode, Electrochim. Acta 54 (2009) 1210-1217.

[18] B. Borbón, M.T. Oropeza-Guzman, E. Brillas, I. Sirés, Sequential electrochemical treatment of dairy wastewater using aluminium and DSA-type anodes, Environ. Sci. Pollut. Res. 21 (2014) 8573-8584.

[19] A. Thiam, E. Brillas, F. Centellas, P.L. Cabot, I. Sirés, Electrochemical reactivity of Ponceau 4R (food additive E124) in different electrolytes and batch cells, Electrochim. Acta 173 (2015) 523-533.

[20] G. Coria, I. Sirés, E. Brillas, J.L. Nava, Influence of the anode material on the degradation of naproxen by Fenton-based electrochemical processes, Chem. Eng. J. 304 (2016) 817-825.

[21] P. Cañizares, J. Lobato, R. Paz, M.A. Rodrigo, C. Saez, Electrochemical oxidation of phenolic compound wastes with BDD anodes, Water Res. 39 (2005) 2687-2703.

[22] E. Brillas, I. Sirés, C. Arias, P.L. Cabot, F. Centellas, R.M. Rodríguez, J.A. Garrido, Mineralization of paracetamol in aqueous medium by anodic oxidation with a boron-doped diamond electrode, Chemosphere 58 (2005) 399-406.

[23] C. Flox, P.L. Cabot, F. Centellas, J.A. Garrido, R.M. Rodríguez, C. Arias, E. Brillas, Electrochemical combustion of herbicide mecoprop in aqueous medium using a flow reactor with a boron-doped diamond anode, Chemosphere 64 (2006) 892-902.

[24] A. Özcan, Y. Şahin, A.S. Koparal, M.A. Oturan, Propham mineralization in aqueous medium by anodic oxidation using boron-doped diamond anode. Experimental parameters' influence on degradation kinetics and mineralization efficiency, Water Res. 42 (2008) 2889-2898.

[25] V. Santos, J. Diogo, M.J.A. Pacheco, L. Ciríaco, A. Morão, A. Lopes, Electrochemical degradation of sulfonated amines on $\mathrm{Si} / \mathrm{BDD}$ electrodes, Chemosphere 79 (2010) 637-645.

[26] N. Oturan, E. Brillas, M.A. Oturan, Unprecedented total mineralization of atrazine and cyanuric acid by anodic oxidation and electro-Fenton with a boron-doped diamond anode, Environ. Chem. Lett. 10 (2012) 165-170.

[27] A. El-Ghenymy, J.A. Garrido, R.M. Rodríguez, P.L. Cabot, F. Centellas, C. Arias, E. Brillas, Degradation of sulfanilamide in acidic medium by anodic oxidation with a boron-doped diamond anode, J. Electroanal. Chem. 689 (2013) $149-157$

[28] C.I. Brinzila, N. Monterio, M.J. Pacheco, L. Ciríaco, I. Siminiceanu, A. Lopes, Degradation of tetracycline at a boron-doped diamond anode: influence of initial $\mathrm{pH}$, applied current intensity and electrolyte, Environ. Sci. Pollut. Res. 21 (2014) 8457-8465.

[29] H. Olvera-Vargas, N. Oturan, E. Brillas, D. Buisson, G. Esposito, M.A. Oturan, Electrochemical advanced oxidation for cold incineration of the pharmaceutical ranitidine: mineralization pathway and toxicity evolution, Chemosphere 117 (2014) 644-651.

[30] E.V. dos Santos, C. Sáez, C.A. Martínez-Huitle, P. Cañizares, M.A. Rodrigo, The role of particle size on the conductive diamond electrochemical oxidation of soil-washing effluent polluted with atrazine, Electrochem. Commun. 55 (2015) 26-29.

[31] A. Bedolla-Guzman, I. Sirés, A. Thiam, J.M. Peralta-Hernández, S. Gutiérrez-Granados, E. Brillas, Application of anodic oxidation, electro-Fenton and UVA photoelectro-Fenton to decolorize and mineralize acidic solutions of Reactive Yellow 160 azo dye, Electrochim. Acta 206 (2016) 307-316.

[32] I. Sirés, P.L. Cabot, F. Centellas, J.A. Garrido, R.M. Rodríguez, C. Arias, E. Brillas, Electrochemical degradation of clofibric acid in water by anodic oxidation. Comparative study with platinum and boron-doped diamond electrodes, Electrochim. Acta 52 (2006) 75-85.

[33] E.B. Cavalcanti, S. Garcia-Segura, F. Centellas, E. Brillas, Electrochemical incineration of omeprazole in neutral aqueous medium using a platinum or boron-doped diamond. Degradation kinetics and oxidation products, Water Res. 47 (2013) 1803-1815.

[34] L. Ciríaco, C. Anjo, J. Correia, M.J. Pacheco, A. Lopes, Electrochemical degradation of ibuprofen on $\mathrm{Ti} / \mathrm{Pt} / \mathrm{PbO}_{2}$ and $\mathrm{Si} / \mathrm{BDD}$ electrodes, Electrochim. Acta 54 (2009) 1464-1472.

[35] C. Salazar, I. Sirés, C.A. Zaror, E. Brillas, Treatment of a mixture of chloromethoxyphenols in hypochlorite medium by electrochemical AOPs as an alternative for the remediation of pulp and paper mill process waters, Electrocatalysis 4 (2013) 212-223.

[36] A. Thiam, M. Zhou, E. Brillas, I. Sirés, Two-step mineralization of Tartrazine solutions: study of parameters and by-products during the coupling of electrocoagulation with electrochemical advanced oxidation processes, Appl. Catal. B 150-151 (2014) 116-125.

[37] A. Thiam, I. Sirés, E. Brillas, Treatment of a mixture of food color additives (E122, E124 and E129) in different water matrices by UVA and solar photoelectro-Fenton, Water Res. 81 (2015) 178-187. 
[38] A. Wang, J. Qu, H. Liu, J. Ru, Mineralization of an azo dye Acid Red 14 by photoelectro-Fenton process using an activated carbon fiber cathode, Appl. Catal. B 84 (2008) 393-399.

[39] A. Khataee, A. Akbarpour, B. Vahi, Photoassisted electrochemical degradation of an azo dye using $\mathrm{Ti} / \mathrm{RuO}_{2}$ anode and carbon nanotubes containing gas-diffusion cathode, J. Taiwan Inst. Chem. Eng. 45 (2014) 930-936.

[40] A. Dirany, I. Sirés, N. Oturan, A. Özcan, M.A. Oturan, Electrochemical treatment of the antibiotic sulfachloropyridazine: kinetics, reaction pathways, and toxicity evolution, Environ. Sci. Technol. 46 (2012) 4074-4082.

[41] A. El-Ghenymy, R.M. Rodríguez, E. Brillas, N. Oturan, M.A. Oturan, Electro-Fenton degradation of the antibiotic sulfanilamide with Pt/carbon-felt and $\mathrm{BDD} /$ carbon-felt cells. Kinetics, reaction intermediates, and toxicity assessment, Environ. Sci. Pollut. Res. 21 (2014) 8368-8378.
[42] I. Sirés, F. Centellas, J.A. Garrido, R.M. Rodríguez, C. Arias, P.L. Cabot, E. Brillas, Mineralization of clofibric acid by electrochemical advanced oxidation processes using a boron-doped diamond anode and $\mathrm{Fe}^{2+}$ and UVA light as catalysts, Appl. Catal. B 72 (2007) 373-381.

[43] J.R. Steter, E. Brillas, I. Sirés, On the selection of the anode material for the electrochemical removal of methylparaben from different aqueous media, Electrochim. Acta 222 (2016) 1464-1474.

[44] F.J. Welcher, Standard Methods of Chemical Analysis, sixth ed, vol. 2, R.E. Krieger Publishing Co, Huntington, New York, 1975. Part B.

[45] APWA, AWWA, WEF, Standard methods for the examination of water and wastewater, Method Number 4500-Cl Chlorine (residual)-G. DPD Colorimetric Method, 21 st ed., American Public Health Association, Washington D.C., 2005, pp. 4-67 and 4-68. 